\title{
ABSTRACTS
}

\section{I. - TRACHOMA}

(1) Morax (Paris).-Bacteriological researches on trachoma in Algeria. (Récherches bactériologiques sur le trachome en Algérie). Rev. Internat. du Trach., July, 1931.

(1) Morax made himself familiar with the cultural phenomena of the bacterium granulosis by studying cultures sent to him from the Rockefeller Institute. He then went to several towns in Algeria where trachoma is rife and inoculated with the products obtained by scraping the diseased conjunctiva the special culture media recommended by the Rockefeller Institute. His results were entirely negative as far as concerns the development on the culture media of bacilli of the type bacterium granulosis.

\section{A. F. MacCallan.}

(2) Olitsky, Knutti and Tyler (New York).-Corneal reactions to bacterium granulosis and other micro-organisms. Jl. of Exper. Med., Vol. LV, pp. 803-813, No. 5, May 1st, 1932.

(2) During the course of studies on the relationship of bacterium granulosis to trachoma, Olitsky, Knutti and Tyler have produced lesions which in their opinion closely resemble the conjunctival lesions of the human disease. However, pannus has not been demonstrated in the experimental disease. Since corneal changes play such an important rôle in trachoma, and inasmuch as similar lesions have not been produced experimentally, the authors have studied the effects of injury to the cornea by various agents. In this way they have sought to determine the type and degree of stimulus necessary to produce pannus.

The action of various micro-organisms, including bacterium granulosis, and of the tissue suspensions was studied both in rabbits and monkeys after intra-corneal injection. In rabbits the bacterium granulosis only induced early uncompliçated and enduring keratitic lesions. 'The results of experiments with monkeys indicate that while pannus is not a sequel of experimental trachomatous conjunctivitis, a lesion resembling it follows intracorneal inoculation of bacterium granulosis.

The items of the bibliography attached to this article do not include Herbert's original and important paper in the Transactions of the Ophthalmological Society of the United Kingdom, Vol. XXIV, pp. 67-77, 1904, entitled "Trachomatous Pannus and 
Associated Corneal Changes," a study of which should precede all experimental and clinical work on trachoma.

A. F. MacCallan.

(3) Talbot (Tunis). - Trachoma in the military territories of Southern Tunisia. (Trachome dans les territoires militaires du sud Tunisien). Rev. Internat. du Trach., January, 1932.

A year of prophylactic trachoma training in Southern Tunisia. (Une année de prophylaxie scolaire du trachome dans le sud Tunisien). Rev. Internat. du Trach., January, 1932.

(3) Talbot is pursuing his important and self-denying work on the epidemiology of trachoma in Tunisia. He considers that contagion is acquired almost invariably in the home by direct and digital inoculation. The better classes who live under better hygienic conditions have a much lower trachoma index than the poorer classes. He adopts the classification of trachoma which is carried out in Egypt, as well as the treatment. But he has to adopt modifications in cases of distant towns and schools where the constant presence of an ophthalmologist is impossible for financial reasons. Full recognition of his labours are due to Talbot both by trachomatologists and by the Colonial Administration of France.

A. F. MacCallan.

(4) Redslob (Strasbourg). - Trachoma in Alsatian soldiers transported to the Russian front. (Le trachome des soldats alsaciens transportés au front russe). Rev. Internat. du Trach., January, 1932.

(4) Redslob calculates that about 300,000 Alsatians were conscripted into the German armies during the War. Of these at least two thirds were sent to the Eastern front for political reasons, where they were billeted among Polish, Lettish, Lithuanian and Ukrainian families. As is well known their hosts are very heavily trachomatised. In spite of this Redslob, who is an ophthalmologist of long experience, and carefully examined the medical reports of all Alsatian soldiers who returned and claimed a pension on account of wound or sickness; has been able to find only three who contracted trachoma while sojourning intimately among a heavily infected and rather dirty population.

This is an interesting and remarkable observation. To Redslob it appears to suggest that Alsatians have some degree of immunity to trachoma. To the reviewer it simply suggests that the Alsatians are men of extremely cleanly habits, who avoided contagion by their good hygienic condition.

A. F. MacCallan. 
(5) Motais (Cochin-China).-Concerning the trachomatous contamination of young European children in the colonies. (Au sujet de la contamination trachomateuse des jeunes enfants européens aux colonies). Rev. Internat. du Trach., January, 1932.

(5) The importance of this reminder by Motais on the danger of allowing European children to be tended by Oriental servants who are or who may be infected with trachoma cannot be emphasised too strongly. Wherever possible the servants should be examined medically before they are allowed to come into any contact with European children. In trachoma countries all servants who come in contact with the children of the house should have some antiseptic drops instilled into their conjunctival sacs daily, and also the children, such as a solution of zinc sulphate 0.25 per cent.

\section{A. F. MacCallan.}

(6) Favaloro (Catania). - Some little known mild forms of trachoma. (Sulle forme attenuate e poco note del tracoma cicatriciale). Ann. di Ottal. e La Clin. Ocul., January, 1932.

(6) Favaloro describes a condition, seen with the slit-lamp, in certain mild forms of trachoma in which diagnosis was uncertain. It takes the form of a network of cicatricial bands enclosing spaces which appear optically empty. This network is situated in the more superficial layers of the conjunctiva but in front of the large vessels. Sometimes this appearance could be seen over the whole conjunctiva but more commonly it was limited, often to the internal and external angles, sometimes to the region of the fornix.

In trachoma, where the cicatricial changes are visible to the naked eye, the slit-lamp does not show the same regular network, but the cicatrices are specially marked in the sub-tarsal sulcus, a region which is generally unaffected in the mild cases which Favaloro is considering in this paper.

\section{HaRold GRIMSDALE.}

(7) Morax (Paris) and Jeandelize (Nancy).-Difficulty in the diagnosis of papillary trachoma. (Difficulté du diagnostic du trachome papillaire). Rev. Internat.du Trach., July, 1931.

(7) Jeandelize saw a patient in December, 1929, who had a slight conjunctivitis of the right eye with a little discharge. The patient lived in a district where trachoma is rare. Examination of the discharge showed the absence of micro-organisms.

A week later there was some oedema of the eyelids and the appearance of follicles gave the picture of a swimming bath conjunctivitis.. But the patient did not frequent swimming baths. The condition became more acute during the next ten days. 
Moráx saw the patient in January, 1930. There was very little discharge. There was a papillary condition of the upper tarsal conjunctiva, and also of both upper and lower fornices. An examination of the conjunctival secretion and of scrapings of the conjunctiva showed a lymphocytosis, but no micro-organisms and no epithelial cell inclusions.

The patient was seen from time to time by Jeandelize during 1930, without any particular change in the condition. In November, 1930 , the left eye, hitherto unaffected, exhibited the same appearance as the right eye. Morax then found cell inclusions in small quantity. The treatment carried out by Jeandelize was a weekly massage with a tampon of cotton wool soaked in a one in a thousand solution of oxycyanide of mercury, while the patient instilled frequently copper sulphate solution, 1.5 per cent., soon replaced by a copper sulphate ointment. By the beginning of March, 1931, the condition was cured leaving the conjunctiva of the left eye intact, but a very slight cicatricial condition of the conjunctiva of the right eye.

The authors consider the case worth recording as the diagnosis was at first uncertain, and as a satisfactory cure was obtained in a compàratively short time. It would have been interesting to have made a slit-lamp examination to note the presence or absence of pannus at any time during the evolution of the cure.

\section{A. F. MacCallan.}

(8) Lumbroso and van Sant (Tunis). - New bacterial cultures isolated in North African trachoma following the technique of Noguchi. (Nouvelles souches bactériennes isolées de trachomateux nord-africains en suivant le technique de Noguchi). Arch. de l'Institut Pasteur de Tunis, June, 1931.

Nicolle and Lumbroso (Tunis).-The bacterium granulosis in its relation to the aetiology of trachoma. (Le bacterium granulosis dans ses rapports avec l'étiologie du trachome). Arch. de l'Institut Pasteur de Tunis, June, 1931.

Nicolle and Lumbroso (Tunis).-Immunity against an experimental re-inoculation with the virus of trachoma after a natural and cured attack of the disease. (Immunite consécutive à une atteinte naturelle et guérie de trachome contre une réinoculation expérimentale de virus). Arch. de l'Institut Pasteur, June, 1931.

(8) In a research which necessitated 2,000 cultures made from 29 cases of active trachoma the authors have never found the bacterium granulosis. They found, however, three types of organisms which bore a varying degree of relationship to Noguchi's organism. 
Cultures of the bacterium granulosis derived from strains isolated by Noguchi and by Olitsky were found to have no pathogenic effect in man when injected under the conjunctiva or into the blood stream. The distinguished authors note that their cultures were. old and may have lost some of their virulence.

Intravenous inoculation with living cultures of the bacterium granulosis, as isolated by Olitsky, does not give any protection against a later inoculation with trachoma virus.

A first attack of natural trachoma which has left as a result a completely cicatricial condition of the conjunctiva, (Trachoma stage IV) puts the subject entirely out of reach of any subsequent experimental re-inoculation with the virus, of any sort or kind whatsoever.

\section{A. F. MacCallan.}

(9) Pergola (Cagliari). - The treatment of trachoma and its corneal complications. (Sulla terapia del tracoma e delle sue complicanze corneali). Lett. Oftal., April, 1932.

(9) Pergola has treated a number of cases of trachoma with Angelucci's "Tracholysin" and has found it of much value. It is given either subconjunctivally or dropped into the conjunctival sac.

As might be expected, the effects are more marked in cases of active trachoma ; in the cicatricial stage with old pannus, there is little betterment.

Harold Grimsdale.

\section{II.-CONJUNCTIVA}

(I) Morax (Paris).-Follicullar conjunctivitis of bathing. (Conjunctivite folliculaire de piscine). Rev. Internat. du Trach., January, 1932.

(1) It is stated by some authors that bathing-pool conjunctivitis is a condition in which the epithelial inclusions of Halberstaedter and Prowaczek may always be found. Morax has found these in one case of bathing-pool conjunctivitis, though in small numbers, but he has also found them in a case of follicular conjunctivitis which had no history of having visited a swimming bath. The author criticises the conception of genital trachoma advanced by Lindner.

A. F. MacCallan. 
(2) Casini (Modena). - Spring catarrh and the seasonal modifications of eosinophilia. (Congiuntivite primaverile e modificazioni stagion le della eosinofilia ematica). Arch. di Ottal., May, 1932.

(2) Casini has examined the blood count in six cases of spring catarrh for several successive months; he has found a constant slight increase of the eosinophils during the late spring and early summer.

Exposure to the ultra-violet rays has very little influence on the eosinophil count but the lymphocytes in all cases increased considerably at the expense of the neutrophils.

Harold Grimsdale.

\section{III.-MISCELLANEOUS}

(I) Davis, F. A. (Madison, Wisconsin).-Tribromethanol as an anaesthetic in eye surgery. (Tribromethyl-Alcohol=Avertin). Trans. Amer. Ophthal. Soc., Vol. XXIX, p. 47, 1931.

(1) Davis has given an account of the history and a survey of the literature and case reports of avertin anaesthesia in British, American and Continental clinics.

Avertin is a white crystalline substance and is prepared by the reduction of bromal hydrate by alcohol in the presence of aluminium ethoxide as a catalyst. It is soluble in water heated to $45^{\circ} \mathrm{C}$. but at higher temperatures becomes toxic.

The dosage is $0.1 \mathrm{gm}$. per kilogram of body weight and is given as a freshly prepared 3 per cent. solution in distilled water at body temperature.

The preparation of the patient consists in the administration of a simple enema 4.5 hours before operation and the injection of morphine grs. $1 / 6$ and scopolamine grs. 1/150 1.5 hours before operation.

The avertin is injected slowly from a large glass syringe through a fine French catheter passed 4 inches into the rectum. The solution is warmed to $40^{\circ} \mathrm{C}$ :, and in order to retain the fluid the buttocks are strapped together with adhesive plaster after removing the catheter. An alternative is the intravenous route, sudden sleep and deep coma being induced in 15-20 minutes.

There is a summary of the results of avertin anaesthesia used in 90 operations in the Eye Clinic of the University of Wisconsin General Hospital, 48 being intra-ocular and 42 extra-ocular. The age of the patients varied from 6 months to 87 years; 56 per cent. were males and 44 per cent. females. The avertin was administered 
at times varying from 5 to 56 minutes before operation, the average being 24 minutes. The duration of the operations was from 1 minute to 1 hour and 10 minutes, the average being 29 minutes.

Observations on the intra-ocular pressure were made and a fall was noted in 38 out of 47 cases. The range of fall was from 2 to $60 \mathrm{~mm}$. of mercury the average being $13 \mathrm{~mm}$. of mercury. No change was present in 5 cases and there was a rise of from $2-13 \mathrm{~mm}$. of mercury in 5 cases associated with respiratory embarrassment. The lowered venous pressure and the diminished respiratory excursions are probably the cause of the lowered tension.

There was a fall of blood pressure in 35 out of 54 cases and a rise in 13. The average fall was $30 \mathrm{~mm}$. of mercury. The venous pressure, taken by the direct method, also showed a fall.

The period of narcosis varied from 15 minutes to 15 hours. One third of the cases required a supplementary general anaesthetic and practically all these were young subjects under 25 years of age.

Anaesthesia was full in 70 per cent. It is important to use a preliminary sedative in strong vigorous men.

The dose used is 0.1 gram. per kilogram of body weight; the smallest dose was 22 c.c. of a 3 per cent. solution and the largest 315 c.c., the average being 145 c.c.

Vomiting occurred in 16 per cent. of cases but it is uncertain whether this was not due to a preliminary injection of morphia or the use of general anaesthesia to supplement the action of the avertin. Avertin used alone rarely produces vomiting.

Observations were made on the character of the awakening; 75 per cent. were quiet and the remainder restless. Backache was complained of in 10 per cent. of the patients, and in two cases there was severe asphyxia.

During operation the eyes were motionless but rotated slightly upwards, the pupil contracted but reacting to light. The tone of the extra-ocular muscles is reduced, the tissues pale, the intra-ocular tension lowered, bleeding lessened, and the lens and vitreous appear to be displaced backwards. In performing cataract extraction. double fixation of the eye is sometimes required.

The advantages of this anaesthetic are the rapid and pleasant induction in bed, amnesia, post-operative sleep, lowered intraocular tension in cases where it has been raised, diminished bleeding and less risk of intra-ocular haemorrhage, and control of the patient during operation.

The disadvantages are the uncertain accuracy of dosage, asphyxia and lowered muscle tone. The insertion of a metal airway and the administration of oxygen do much to combat asphyxia.

Thirty references are given at the end of this paper and the author concludes that avertin is a valuable adjunct in ophthalmic operations in selected cases.

H. B. Stallard. 
(2) Rabkin, E. B. (Kharkdow, Ukraine).-Post-operative care without bandages. Arch. of Ophthal., June, 1932.

(2) Rabkin was able to note the effect of the open method of post-operative treatment at Professor Hirschmann's Ophthalmic Institute in Kharkow. The cases numbered 127, and comprised cataract extractions, iridectomies, etc. No complications occurred as a result of using the open method, and the post-operative stay in hospital was shorter than when bandages were used. The method is not advised in cases where the wound is gaping, where haemorrhage is present, or when there is glaucoma with high tension. Also in cases of squint operations, where it is desired to immobilise the eyes, bandages are of course advisable. The "open method" is not described in detail, but it would seem to consist in placing a single layer of gauze over the eyes and tying it posteriorly. The layer of gauze is used not for protection but merely to allay the anxiety the patient might feel if the eyes were left completely uncovered.

F. A. W-N.

(3) Ishikawa, F. (Sendai).-Experimental glaucoma in the dog with special reference to changes in the optic nerve. (Experimentelles Glaukom beim Hunde mit besonderer Rücksicht auf Sehnervenerkrankungen). Arch.f. Ophthal., Vol. CXXIV, p. 387.

(3) By the injection of suspensions of hair-pigment into the anterior chamber Ishikawa produced in dogs a clinical picture similar to that of acute glaucoma in man (viz. sudden rise in tension and marked inflammatory symptoms), together with a rapidly increasing hydrophthalmic enlargement of the eyeball, the sclerotic being stretched throughout its circumference. If the tension remained high for some time, the sclerotic usually showed some degree of compensatory hypertrophy.

He discusses the changes in the parenchyma and fixed cells of the cornea that account for the diffuse corneal opacity, and the degenerative changes in the retina, which are regarded as not specific for experimental glaucoma.

With regard to the main part of this research, which was to decide whether there was any connection between the spaces of Schnabel in the optic nerve and the glaucomatous excavation of the optic disc, the author found these spaces most marked in the intralaminar portion of the nerve, less so in the retrolaminar. The prelaminar portion usually shows cavernous degeneration at a much later stage, and then only to a slight extent.

It seems probable that glaucomatous atrophy of the optic nerve with a varying degree of proliferation of the glia may develop 
even without a preceding cavernous degeneration of the nerve fibres.

The spaces of Schnabel are almost invariably microscopically small, and even by fusing together would hardly ever attain such a size as later to cause a contraction of the remaining glia and connective tissue.

In none of the cases was there any sign of a transition of these spaces into a real glaucomatous excavation of the optic papilla; it is reasonable to suppose that with the advancing optic atrophy they gradually become fewer and finally disappear owing to the proliferation of the glia.

The essential factor in the development of the excavation in the disc is the pathological rise in the tension.

Cavernous degeneration of the optic nerve in glaucoma is, in his opinion, brought about by the effect of the backward displacement of the lamina cribrosa on the optic nerve fibres; these fibres, which are in close union with the meshwork of the glial portion of the lamina, undergo great stretching, squeezing, and finally rupture, and hence the development of these spaces is most pronounced in the intralaminar portion of the nerve.

Thos. SNowball.

(4) Accardi and Fontana (Palermo). - Effect of vital colouring on the intra-ocular tension, the diameter of the pupil, the albuminous content and refractive index of the aqueous humour. (Effetti della colorazione vitale sulla tensione endoculare, diametro pupillare, tasso albiminoideo e indice di rifrazione dell' umore acqueo). Boll. d'Ocul., January, 1932.

(4) In their study of the reticulo-endothelial system of the eye, Accardi and Fontana have been naturally led to consider the possible importance of the system, which makes such a large part of the uveal tract, in the production of the aqueous humour.

They have no doubt that the injection of vital dyes, colloid metals and other such bodies, during life, affords one of the best means at our disposal of examining the functions of this system. They have followed the changes of intra-ocular tension in rabbits in which these injections have been made. They have found in all cases an increase of the pressure together with an increase of the albuminoid content and of the refractive index of the aqueous. Since the same results followed the injections of different substances and different amounts of the same substance, they conclude that partial physiological block of the system plays an important part in the production of these phenomena.

Harold Grimsdale. 